\title{
A scientific note on virgin queen acceptance in stingless bees: evidence for the importance of queen aggression*
}

\author{
Stefan JARAU ${ }^{1}$, Johan W. van VEen ${ }^{2}$, Ingrid AguilaR ${ }^{2}$, Manfred AYASsE ${ }^{1}$ \\ ${ }^{1}$ Institute for Experimental Ecology, University of Ulm, Albert-Einstein-Allee 11, 89081 Ulm, Germany \\ ${ }^{2}$ Center for Tropical Bee Research (CINAT), National University of Costa Rica, PO Box 475-3000, Heredia, Costa Rica
}

Received 10 February 2009 - Revised and accepted 16 April 2009

stingless bee / Melipona beecheii / queen acceptance / dominance behavior / physical aggression

Stingless bees (Apidae, Meliponini), which are close relatives to honey bees (Apidae, Apini) and share with them a highly eusocial colonial organization (Michener, 2000), are remarkable for their habit of producing virgin queens throughout the year (Engels and Imperatriz-Fonseca, 1990). Most of these queens are not needed for a colony's survival or division, however, and get executed some time after their emergence (Imperatriz-Fonseca and Zucchi, 1995). Only little is known about the mechanism that releases the execution behavior in workers or about how a particular virgin queen is chosen as a new queen. Recently, we found that in Melipona beecheii a virgin queen's conspicuous behavior, which consists of rapidly running over the brood area, thereby making spinning movements and beating her wings, triggers the worker attacks (Jarau et al., 2009). A chemical signal or cue potentially released by such queens seems not to account for her execution. Virgin queens were never attacked as long as they sat motionless on the comb and the number of aggressive worker attacks significantly decreased from 15 to zero within $10 \mathrm{~min}$ when we made an active virgin queen "behaviorless" through freezing (for details see Jarau et al., 2009). During our study, in which we observed the virgin queens' behavior and interactions with workers in small observation boxes that contained a comb of approximately 200 cells and initially 2530 adult bees (the number of which increased as further bees emerged from the cells), we registered one

Corresponding author: S. Jarau,

stefan.jarau@uni-ulm.de

* Manuscript editor: Stan Schneider interesting case of queen acceptance, on which we report in the following.

On the 21st day after we established an orphan condition in our observation boxes, we observed a virgin queen (marked with color the first time we saw her) that was not aggressively attacked by the workers, as is typical during queen elimination in M. beecheii (Jarau et al., 2009). Instead, she actively contacted the workers and bumped into them, often bringing herself into close lateral contact with a worker and quickly shaking her abdomen in a wagging movement, thereby pushing the workers away. The virgin queen's aggressive behavior continued for the following three days, but on the fourth day she slowly walked through the observation box without bumping into workers. By that time she apparently was accepted by the workers and the observed calm behavior continued until the end of our observations nine days after first seeing her. During that time we observed only one further virgin queen, which was killed by the workers, and no males emerged from the brood cells. Since the observation box was not connected to the outside the accepted queen could not leave for a nuptial flight.

The virgin's aggression towards the workers, especially the conspicuous abdomen shaking after she brought herself into a position side to side with a worker, likely is an essential stage in the establishment of her dominance by means of direct physical aggression. In accord with our observation Silva et al. (1972) reported that a M. quadrifasciata virgin queen began touching the vertex of workers with her mandibles and forelegs on the third day after emergence and considered this behavior a kind 
of dominance-subordination mechanism. Likewise, Engels and Imperatriz-Fonseca (1990) mention that in a variety of non-Melipona species interactions between workers and virgin queens switch from an initial worker- to queen control (without giving details, however). These observations are of interest because the establishment of a single dominant female by means of overt aggression is regarded characteristic of primitive insect societies (Wilson, 1971). We assume, that in highly eusocial stingless bees a virgin queen's physical aggression is important for the initial establishment of her dominance over the workers, too. Once her dominance is established, however, she probably can be recognized by the workers by her specific - maybe individual - cuticular hydrocarbon pattern. Her aggressiveness then ceases, which finally may lead to the ritualized dominance behavior that is typical for physogastric queens in stingless bees (Zucchi, 1993). In addition, virgin queens may produce pheromones - the composition of which may change in time - that could lead to their acceptance. However, the existence of such pheromones remains to be shown to this day.

The scenario described above is based on occasional observations only and should be investigated in greater detail with a larger number of observed acceptances of virgin queens in stingless bees. However, the proposed predominant role of a virgin queen's behavior for the establishment of her dominance over the workers is in line with the demonstrated importance of her behavior during the queen elimination process (Jarau et al., 2009) as well as with the known importance of ritualized dominance behavior of physogastric queens (Zucchi, 1993). Interestingly, in these aspects stingless bees markedly differ from honey bees, where such agonistic behavioral interactions with workers are lacking and where a queen's identity and presence as well as her dominance position are predominantly communicated by means of pheromones (Free, 1987; Winston, 1987).

\begin{abstract}
Note scientifique sur l'acceptation d'une reine vierge chez les Abeilles sans aiguillon : mise en évidence de l'importance d'un comportement agressif chez la reine.
\end{abstract}

Eine wissenschaftliche Notiz über die Akzeptanz von Jungköniginnen bei stachellosen Bienen der Gattung Melipona: Hinweise auf die Bedeutung des aggressiven Verhaltens der Königinnen.

\section{REFERENCES}

Engels W., Imperatriz-Fonseca V.L. (1990) Caste development, reproductive strategies, and control of fertility in honey bees and stingless bees, in: Engels W. (Ed.), Social insects: an evolutionary approach to castes and reproduction, Springer, Berlin, Heidelberg, New York, pp. 167230.

Free J.B. (1987) Pheromones of social bees, Comstock Publishing Associates of Cornell University Press, Ithaca, New York.

Imperatriz-Fonseca V.L., Zucchi R. (1995) Virgin queens in stingless bees (Apidae, Meliponinae) colonies: a review, Apidologie 26, 231-244.

Jarau S., van Veen J.W., Aguilar I., Ayasse M. (2009) Virgin queen execution in the stingless bee Melipona beecheii: the sign stimulus for worker attacks, Apidologie 40, 496507.

Michener C.D. (2000) The bees of the world, The Johns Hopkins University Press, Baltimore, London.

Silva D.L.N. da, Zucchi R., Kerr W.E. (1972) Biological and behavioural aspects of the reproduction in some species of Melipona (Hymenoptera, Apidae, Meliponinae), Anim. Behav. 20, 123-132.

Wilson E.O. (1971) The insect societies, The Belknap Press of Harvard University Press, Cambridge, Massachussets, London.

Winston M.L. (1987) The biology of the honey bee, Harvard University Press, Cambridge, Massachussets, London.

Zucchi R. (1993) Ritualized dominance, evolution of queenworker interactions and related aspects in stingless bees (Hymenoptera: Apidae), in: Inoue T., Yamane S. (Eds.), Evolution of insect societies, Hakuhinsha, Tokyo, pp. 207-249. 